Article

\title{
Exploring Employability Constructions of Migrants in Sweden and Potential Consequences for Labour Market Entrance Recommendations
}

\author{
Hanna Li Kusterer ${ }^{1, *(1)}$ and Claudia Bernhard-Oettel ${ }^{2}$ \\ 1 Department of Occupational Health Sciences and Psychology, Faculty of Health and Occupational Studies, \\ University of Gävle, 80176 Gävle, Sweden \\ 2 Department of Psychology, Stockholm University, 10691 Stockholm, Sweden; claudia.bernhard.oettel@su.se \\ * Correspondence: hanna.kusterer@hig.se
}

Received: 9 December 2019; Accepted: 27 February 2020; Published: 4 March 2020

\begin{abstract}
In the flexible Swedish labour market, the concept of employability has grown important. Within a neoliberal framework, accountability for one's possibility to successfully obtain or keep employment rests with the individual. In contrast, within a social welfare discourse the individual is offered care and support in order to gain employment. The present study combined intersectional and discourse analytical approaches with the understanding that individual employability is subjectively constructed in the exploration of labour market induction, employability constructions and categorizations in the discourse used by government agencies directly involved in the labour market integration of newly arrived migrants. Public documents comprising information on labour market entrance, employability and associated concepts such as competence building and career development were analysed. The employability constructions were often contradictory-placed at the crossroads of neoliberal and social welfare discourses-and built on tacit assumptions and influenced by stereotypes. Conveying such employability constructions further could lead to exclusion from long-term employment and have detrimental psychological and health repercussions. Instead, it is of importance to work towards reconstructing migrants' employability in this new context without damaging influence from inflexible categorizations and stereotypes.
\end{abstract}

Keywords: employability; migration; labour market induction; newly arrived migrant

\section{Introduction}

Swedish society and its labour market are changing constantly, and some of the most notable changes are those regarding immigration and labour market integration policies (e.g., Irastorza and Bevelander 2017). After entering the European Union in 1995, Sweden continued to admit a relatively large number of refugees at the same time as migration to and from other EU countries increased (see Diedrich 2017). In 2015, over 160,000 asylum seekers arrived (Swedish Migration Agency 2018a), and over 100,000 people who were granted asylum in 2016-2017 (Swedish Migration Agency 2018b) are somewhere in the process of relocation, labour market entry, and integration.

In this article, we will focus on representations and ascriptions of migrants' employability and study in what way these may constrain or open up for a satisfactory labour market entry. By satisfactory, we mean both successful from a governmental perspective in terms of, for example, more people entering the labour market in a shorter time, but just as importantly, satisfying for the individuals. We will argue that a combination of theoretical perspectives is necessary in order to interpret these employability representations and ascriptions, and we will bring together intersectional, discourse analytical and psychological approaches in the exploration of migrants' construed employability. 
The present study will focus on government agencies directly involved in the labour market integration of newly arrived migrants. While the present article will not go into the difficult issue of defining and categorizing people who migrate for various and complex reasons (see Crawley and Skleparis 2018), a short elaboration of our use of various terms may be called for. According to the terminology used in Sweden, 'migrant' can be broadly used to denote an individual who is on the move, without entailing any reason for moving to Sweden or necessarily indicating the application for (temporary or permanent) residence permit ${ }^{1}$. Furthermore, 'immigrant' is an even broader term, often denoting people who are either born outside of Sweden and/or have two parents born outside of Sweden. Newly arrived migrant/immigrant, on the other hand, is a narrow term denoting someone who has applied for and been granted asylum (hence, not previously resident in the EU), and thereby received a residence permit (temporary, as of 21 July 2016). A newly arrived migrant is eligible for certain types of labour market measures that are managed by the Swedish Public Employment Service (PES). An individual is only eligible for these measures during a specified period, and according to this categorization, the term newly arrived is no longer used when this time has passed.

In the present article, we use the term migrant for all people who have been on the move (and are currently residing in Sweden), which could include third country nationals as well as EU-residents. We use newly arrived migrant in a less strict sense compared to the PES, but still denoting someone who is new to Sweden and in need of labour market induction. The outline of the article is as follows: First, a background on the Swedish context and relevant research is presented; second, our theoretical background, supported by empirical research, is developed, before the aims and specific research questions are explicated. This is followed by a description of the materials and methods, results, discussion and finally a concluding section.

\section{Background}

The Swedish labour market is characterised by a flexible working life and a high labour force participation of both women and men, which is at least partly enabled by a strong welfare state including state benefits for parental leave and guaranteed childcare provision. Although Sweden is considered one of the most progressive countries in terms of gender equality (e.g., World Economic Forum 2020), the labour market is strongly gender segregated both vertically and horizontally, and women take the vast majority of the parental leave as well as responsibility for child care and domestic chores (Statistics Sweden 2018). Comparing residents born in Sweden to migrants, there are large differences, for example, regarding unemployment rates and participation in the labour force, and these differences often vary depending on gender (Statistics Sweden 2014, 2018). Migrants participate in the labour force to a much lesser extent than Swedish-born residents do; a pattern that is particularly prominent for women. It is also difficult for migrants with completed university degrees to obtain employment on par with their academic levels (c.f. Larsen et al. 2018). The number of unemployed Swedish-born residents has decreased in recent years, but unemployment levels among migrants has increased and remains high (Swedish Public Employment Service 2017a; 2018b). Furthermore, migrants are overrepresented among people in long-term unemployment (Swedish Public Employment Service 2017a; 2018b) and are more likely than Swedish-born to transition from temporary employment to unemployment or leaving the labour force (Berglund et al. 2017). Generally, the gap between Swedish-born residents and migrants is more pronounced for refugees. Many of the differences can be explained with the help of demographic variables, such as educational level. In migration research, a distinction between skilled and low-skilled migrants is often made. Yet, as van Riemsdijk et al. (2016) point out, this differentiation may be oversimplified, since even high-skilled migrants' degrees are undervalued (see

1 For example, the predominantly Romani Romanians who try to support themselves financially by begging for money are labelled "EU-migrants", although they are only allowed to stay in Sweden for a maximum of three months under these conditions. 
also Eggenhofer-Rehart et al. 2018; Mancinelli et al. 2010). Thus, both open and more subtle or hidden discrimination are likely to emerge, and this has been found in evaluation and validation procedures of migrants' prior learning (e.g., Diedrich 2017; Diedrich and Styhre 2013; Saxonberg and Sawyer 2006). Discriminating structures and processes within organizations, regarding ethnicity, gender, age or class background, often operate together (Acker 2006). Within intersectional perspectives, it is recognized that the creation of subject positions or identities are drawn from a multitude of social categorizations (e.g., gender, race, class, sexuality, disability, age, see Acker 2006; Browne and Misra 2003; De los Reyes 2014). People who are ascribed categorizations with limited power for action and change are at risk of being confined by socially constructed, and often contradictory, frames of explanation (e.g., Browne and Misra 2003; Kelan 2014; Kusterer 2014). With respect to labour market entry, such positions of (limited) power for action and change are often tied to perceptions and categorizations regarding an individual's employability. Employability can relate to tangible assets, such as education and previous work experience, but these assets need to be evaluated and made sense of. For newly arrived migrants, their ways of constructing their own employability in a new context can be very challenging, especially if the cultural norms in the old and new country differ greatly (Eggenhofer-Rehart et al. 2018). Various intermediaries and gatekeepers in the labour market can play an important role in this process, but they can also restrict the reformulation of employability and social capital (Aslan et al. 2019; Eggenhofer-Rehart et al. 2018; Pajic et al. 2018).

There are both challenges and possibilities facing the newly arrived migrants and Swedish society and labour market. Many people need employment and employers need to be able to utilize and develop their skills and competences (Swedish Public Employment Service 2016a). This process is far from an easy endeavour (e.g., Diedrich 2017). As previous research has pointed out, participation in the labour market is an important component of integration and social inclusion (e.g., Aslan et al. 2018; van Riemsdijk et al. 2016). In addition, paid employment is the main road towards securing permanent residency (SFS 2016:752 2016). Therefore, it is important to study all facets of labour market induction, integration and inclusion (and lack thereof). The present study tries to expand the body of research by focusing on the early part of this process-information on establishment in a new country and the steps before any actual labour market entrance.

\section{Theoretical Framework}

\subsection{Labour Market Induction: Neoliberal Discourses Meet Social Welfare Discourses}

Present day society and working life is increasingly attuned to the neoliberal view of people as free and transferable individuals with the capacity to make their own decisions on all aspects of education, work, and career development (Aslan et al. 2019; Davies et al. 2005; Fejes 2010; Garsten and Jacobsson 2013; Gazso 2007). Alongside and within the expansion of neoliberal frameworks and procedural developments in Sweden, the concept of employability has received more and more attention (e.g., Diedrich and Styhre 2013; Fejes 2010; Garsten and Jacobsson 2013). Employability can be described as one's ability to obtain employment, change or keep one's job (Berntson 2008; Berntson et al. 2008). Within a neoliberal framework, it is a form of individual responsibility and self-determination or self-government, where accountability for one's own employability rests with the individual (Fejes 2010; Garsten and Jacobsson 2013). This framework is in sharp contrast to the social welfare discourse, which presents newly arrived migrants-and refugees and asylum seekers more generally-in the need of care, nurture and support (c.f. Diedrich and Styhre 2008; Eliassi 2015). Thus, within the framework of a social welfare discourse, instead of active agents, migrants are portrayed as passive recipients or problematic cases, and this contradicts the neoliberal ideas of the capable job seeker in charge of their own job opportunities and career development. The contradictions are brought to light in the public discourse, which rests on the idea that an individual's employability is essential in getting a job. Superficially, this standpoint entails a belief in an objectively measurable employability concept, and the equal treatment of all employees (and potential employees), with judgments based on 
obtained qualifications and competences, and irrespective of attributes such as gender and ethnicity. However, norms, presuppositions, and contradictions within neoliberal discourses suggest otherwise (c.f. Allen et al. 2013; Calas and Smircich 2006; Kusterer 2014).

Rather than being a stable and isolated concept without influence from the surrounding conditions, how employability is constituted and what it is considered to be is contingent on the social context and what categorizations are highlighted, for example, by Public Employment Service representatives (e.g., Diedrich and Styhre 2013; Garsten and Jacobsson 2013). Hence, although based on tangible assets, it is socially constructed and fluid. Diedrich and Styhre (2013) as well as Vesterberg (2013, 2015, 2016a) problematize the construction of migrants as lacking employability within a neoliberal policy discourse. These researchers thus investigated how migrants' (lack of) employability is construed by others, within a context of the predominant neoliberal perspective. They raise difficulties and contradictions in efforts to construct migrants as employable within this discourse. Vesterberg (2016b) argues that within the dominant policy discourse, in order to become included and employable, the migrant must first be excluded and unemployable. Only by being considered unemployable is the migrant eligible for labour market measures to counter unemployment and lack of employability, and can thereby have the potential to increase employability. Hence, how employment opportunities are presented and employability is constructed by public officials can be of vital importance (see also Aslan et al. 2019), and this is something in need of further research attention.

\subsection{Gender and Intersectionality}

From a social constructionist perspective, gender and gender differences are assumed to be social constructions without definite borders, essence or stability (see, e.g., Acker 2006; Calas and Smircich 2006). Along with, for example, ethnicity, class/socioeconomic status, age, and cultural background, it is constantly performed and accomplished (see, e.g., Martin 2003; 2006; West and Zimmerman 1987). The meaning and alleged importance of an individual's type and level of education can also be considered socially constructed and fluid. Using an intersectional approach, it is of interest to explore how subject positions or identities are construed from several intertwining social categorizations (Acker 2006; De los Reyes 2014). Inherent in these social constructions are the varying possibilities to exert power; possibilities that are intrinsically linked to high status positions such as being white, male, and able-bodied (Acker 2006; De los Reyes 2014). These social categorizations are more often than not taken for granted (c.f. Acker 1990). That is, categorizations are highlighted when they appear contrary to a norm: for example, the lack of Swedishness (c.f. Eliassi 2015; Vesterberg 2015).

\subsection{Merging Perspectives: Constructions of Individual Employability}

Employability as a psychological concept comprises the individual's subjective perceptions, personal characteristics, and their reflections and interpretations of the structural factors of the labour market (see, e.g., Berntson 2008; Fugate et al. 2004). Perceptions of one's own employability are shaped and constructed vis-à-vis the situational context. Feeling employable can be regarded as an individual resource important for health, career development, and possibilities to assert influence in an organization, or a generic competence or ability (c.f. Berntson 2008; Miller et al. 2013; Vanhercke et al. 2014). Previous research using quantitative measures has shown that men, highly educated, and older people tend to interpret their employability as higher than women, people with lower education, and younger people (e.g., Berntson 2008; Berntson et al. 2006; Mäkikangas et al. 2013). Croucher et al. (2018) investigated employability perceptions among low-paid workers of different ethnicities in London, and found that education and work experience had a positive relationship with favourable employability constructions, but they also found great variability within different ethnic groups and lesser diversity across groups. These results resonate with Vertovec (2007) notion of Britain's (and particularly London's) superdiversity, which entails a high level of complexity among diversifying dimensions such as country of origin, gender and educational background. For the purposes of 
the present paper, it underlines the contextualised and fluid constructions and reconstructions of employability, as well as the importance of an intersectional approach.

\subsection{Aims and Research Questions}

Previous research has shown the importance of employment for social inclusion and integration of migrants (e.g., Aslan et al. 2018; van Riemsdijk et al. 2016), and public officials can play an important role in facilitating the process towards gaining employment (Aslan et al. 2019; Eggenhofer-Rehart et al. 2018; Pajic et al. 2018). An individual's perception of their employment opportunities is influenced by a number of aspects, among them ascriptions of employability, suggested guidance and information provided by government officials, Public Employment Service representatives, and recruitment agents. Even though perceived employability does not inevitably follow from or attune to others' ascriptions and categorisations (e.g., Vesterberg 2016b), exploring such constructions is one step towards an increased comprehension of how a migrant may perceive their employability, and make sense of their employment opportunities in a new context. We recognize that our exploration is focused on a Western context that may differ from the migrants' predominantly non-Western contexts of origin. This entails a reformulation of employment opportunities and revaluation of previous education and/or work experience, usually to the disadvantage of the individual migrant (e.g., Eggenhofer-Rehart et al. 2018; Larsen et al. 2018; Mancinelli et al. 2010; van Riemsdijk et al. 2016). In the present study, we combine intersectional and discourse analytical approaches with the understanding that individual employability is subjectively constructed in order to explore labour market induction, employability constructions and categorizations in the discourse used by government agencies directly involved in the labour market integration of newly arrived migrants.

Our analysis bears similarities to Fejes (2010) and Vesterberg (2016b), in that we examine how the employable individual is constituted, and how discourses on employability are mobilised. However, instead of a governmentality perspective and focus on policy implications, we are primarily interested in how an employable individual is constructed and what this construction demands from the individual as well as enables one to do. Furthermore, we aimed to explore what implications these discourses and constructions may have for labour market induction of migrants placed in particular social categories, depending on, for example, vocational and educational background, gender, and country of origin.

\section{Guiding Questions}

- How is labour market introduction and establishment described, and what explicit and implicit information is conveyed in these descriptions for the construction of migrants' employability?

- What social categorizations are highlighted, and in what ways do they-explicitly or implicitly—relate to constructions of migrants' employability?

\section{Materials and Methods}

The present study made use of public documents as its source of data. Although often used in combination with other qualitative research methods, document analysis can be employed as a standalone method, and can be particularly useful in circumstances such as the present. Aiming to explore social constructions in the discourse, text analysis of published documents is a recommended method (e.g., Bergström and Boréus 2005; Braun and Clarke 2013). We were able to benefit from the lack of obtrusiveness in gathering data, the non-reactive form of the material, as well as the possibility to sample widely and make use of a variety of materials (e.g., Bowen 2009). In gathering the material, a well-thought out sampling strategy is of importance. However, there is no single prescribed procedure; rather, both sampling and analytical approach need to be in accordance with the aim of the study and adjusted to contextual features (Bergström and Boréus 2005; Braun and Clarke 2013). 
Our strategy was to approach the search for materials as two individuals without Swedish qualifications who recently moved to Sweden looking for work ${ }^{2}$. Because the Swedish Public Employment Service (PES) is responsible for labour market induction, establishment, and re-establishment, we started at the main page of their website. The search focused on information relevant to newly arrived migrants, mainly information on establishment measures and other education and training programmes targeting third country nationals. However, because the main course of action towards permanent residency, for all people migrating to Sweden, is to secure employment ${ }^{3}$ (Swedish Public Employment Service 2019), materials directed at broader groups, such as job-searching migrants in general, and measures to resist long-term unemployment are relevant as well. This search was reiterated with a different focus depending on level and type of education, specific professions (sought-after professions; those requiring a license to practice, etc.), language skills (comparing information in Swedish and English), and parental status. As we navigated through the webpages, we took notes on the process, including difficulties in finding material and reflections on the (in)consistency between how information is presented and what is required from an individual to be eligible for certain labour market induction measures (c.f. Bowen 2009, on the usefulness of documents, while being incomplete and/or imbalanced). A preliminary search was conducted in April 2016. During 2017, we performed searches at three separate occasions (February, May and October). A summary of the materials is presented in Table 1. In order to complement the material directed at migrants and other job seekers, and to further the understanding of migrants' employability constructions as used by the relevant authorities, we collected reports concerning migrants' labour market induction issued by these organizations (see Table 1). All the materials were publicly available and accessed online. In addition, we had access to materials from the project tutors for study guidance (education programme targeted at migrants), which provided us with a more detailed understanding of a particular labour market induction measure.

Information on the relevant webpages is presented in Swedish and English. Materials targeted at (newly arrived) migrants are generally available in the most common migrant languages: Arabic, Dari, Somali, Tigrinya, and Persian, with some information also available in Russian. In addition, information not particularly targeted at newly migrants is available in Sweden's minority languages (various kinds of Sami, Finnish, Romani and Yiddish). We collected materials associated with employability, the job searching process, competence and career development, and validation procedures of qualifications, skills, and experiences. Some of this material is specifically targeted at certain groups of job seekers (e.g., newly arrived migrants) or professions (e.g., self-assessment questionnaires for specific vocations, information regarding validation of skills and/or training for professions with a shortage of employees and/or requiring a license to practice), but others are more general (e.g., tips on how to write a CV or behave during a job interview). Because many of the labour market measures and programmes for newly arrived migrants are coordinated or organized by the PES, and most of the information introducing newly arrived migrants to the Swedish labour market is conveyed by them, their website contain a large proportion of the relevant materials. Via PES webpages, we were also directed to information from other organizations, namely the Swedish Migration Agency, the Swedish Council for Higher Education (UHR), universities providing programmes or courses for newly arrived migrants, providers of Swedish language courses (SFI), and SACO, the Swedish Confederation of Professional Associations, a central organisation for 23 unions for university graduates in Sweden that provided guidance for newly arrived university graduates.

2 Incidentally, this is something both of us have had experience with before entering a PhD programme in Sweden.

3 Due to space limitations, the present article does not take account of entrepreneurship/self-employment, although it is highly relevant both regarding employability constructions more generally and as a means towards obtaining permanent residency (SFS 2016:752 2016). 
Table 1. Summary of materials.

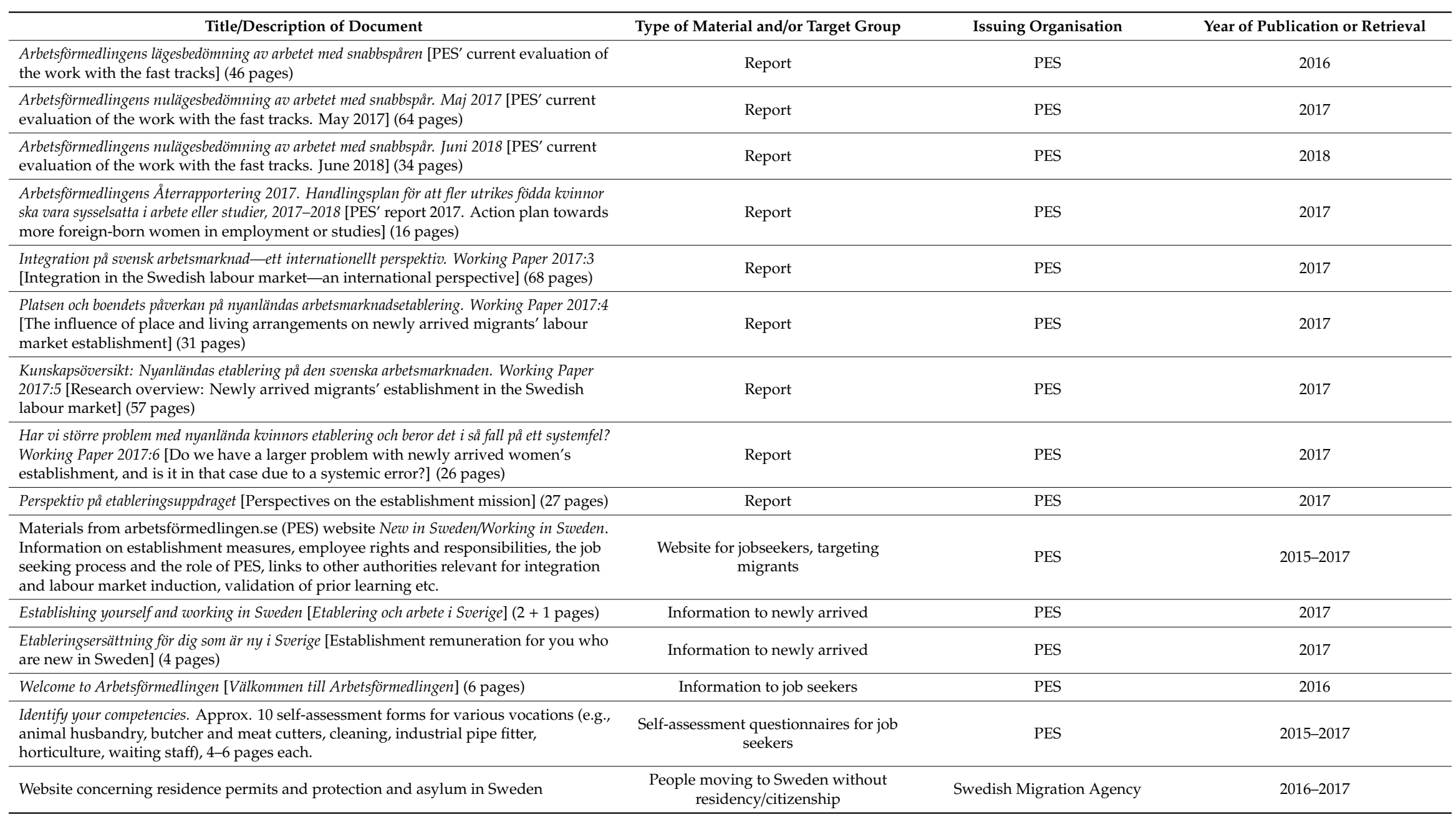


Table 1. Cont.

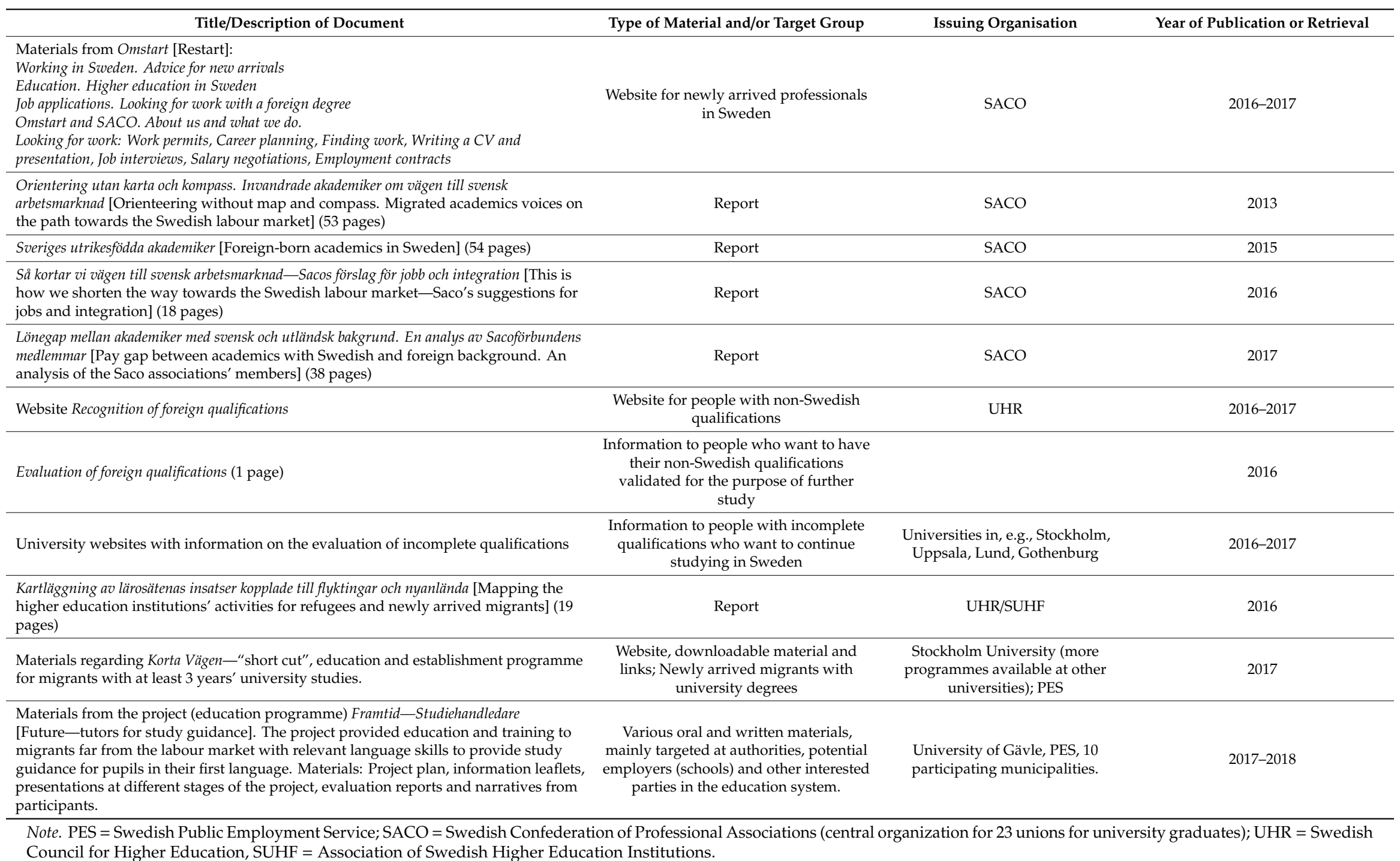

Council for Higher Education, SUHF = Association of Swedish Higher Education Institutions. 
Analysis

We used a discourse analytical approach focusing on prescribed and desired behaviours and attitudes in the construal of an employable individual, and interpreted the material through an intersectional lens on the social categorizations that emerged. Within a discourse analytical perspective, language is considered to entail several, and often competing, patterns of interpretation, or discourses (e.g., Fairclough 2003). A discourse makes some subject positions available for particular individuals, and limits other subject positions, partly in its presuppositions, or taken-for-granted knowledge and tacit assumptions (c.f. Gazso 2007; Kusterer 2014). Discourse constructs objects of problematization (e.g., migrants), and in this way, it can legitimate exclusionary practices (see Eliassi 2015). Hence, language and discourse can have material and practical as well as psychological implications. Moreover, nearly all social practices have discursive components, and it is often close to impossible to separate the discursive practices from the non-discursive. For the purposes of the present analysis, we specifically paid attention to the content as well as the interpersonal aspect of the text material. This means that we analysed what kind of idea or description of reality the text producer communicates, and what kind of action this may evoke in the receiver of the text (Bergström and Boréus 2005). Since both aspects of language use are present in every text, it is difficult if not impossible to separate our initial part of the analysis that mainly focused on understanding and sorting the contents of the collected material and the comprehension of actual procedures for labour market entrance from the latter part of the analysis containing the more discursive elements.

Steered by the guiding questions, we examined how an employable individual is constructed and what this construction demands from the individual as well as enables one to do. This meant reading through the materials and looking for information presented to (unemployed) newly arrived migrants on what is required, needed or wanted from them, as well as what is offered to them from PES and other institutions, in order to obtain employment. No particular software was used; instead, we created mind maps, used comments and highlighting functions in our word processing software, and wrote memos. We also searched for information on what appears to be lacking in terms of employability in newly arrived migrants. Relevant for the present study are the conflicting presuppositions involved in neoliberal versus social welfare discourses, as explicated in the introduction. Both of these discourses were identified in the material and were consequently used as alternative interpretative perspectives. The guiding questions also helped to sort the materials and structure the analysis. Answers to the first question, on how labour market introduction is described, was mainly found in the materials directed at migrants and other job seekers, while the second question, on social categorizations, was mainly answered through the reports. Accordingly, our findings are organized under headings derived from these questions.

When possible, we compared the Swedish and English versions of the same text (directed at migrants). They vary somewhat in elaboration as well as in accentuation. The Swedish material tend to emphasize possibilities for employment and career advancement, while the English material tend to focus on demands and difficulties in entering the Swedish labour market.

\section{Results}

\subsection{Starting Point: Establishment and Labour Market Introduction via PES}

The information pamphlet Establishing yourself and working in Sweden is directed at newly arrived migrants who have been granted asylum. It complements the more general information targeted more widely ("Welcome to Arbetsförmedlingen", Swedish Public Employment Service 2016b), and outlines the process towards establishment in Sweden with the aim of finding a way to support oneself by means of an employment. This process is supposed to start already while the asylum seeker is waiting for the possibility of a residence permit. An important part of the process appears to be the introduction plan, which comes after introductory interviews (one at the Swedish Migration Agency and one at the PES). Already at the interview preceding the formulation of the plan, the newly arrived 
migrant, who has just received a residence permit, has been asked to discuss their "ambitions, interests, and talents", which alludes to phrases used in a recruitment interview or in formulating a personal marketing strategy (work persona) in line with a neoliberal perspective on employment possibilities. The introduction plan is described as follows:

Based on the interview, we'll work out a plan together for how you'll find employment, get an education, or start your own business. In the plan, we'll also take up how your opportunities are affected by where in Sweden you live. We'll start with your opportunities and desires, and support you along the way, but you yourself must be active in order to find the way to your own livelihood. (p. 1)

That is, the plan should be developed by the newly arrived migrant and PES representative in collaboration, but ought to start with the migrant's "opportunities and desires". A social welfare discourse is evident in the quote, with parts such as "we'll work out a plan together" and "support you along the way". However, at the end, "you yourself must be active in order to find the way to your own livelihood" is rather a soft way of stating the neoliberal conclusion that everyone is responsible for their course of action in the search for work and ultimately build the capacity to support oneself financially. The information pamphlet written in Swedish tacitly assumes a neoliberal stance. The English version is twice as long, has more guiding information, and offers help and support from the PES that appears far-reaching. There are many examples of a language that alludes to social welfare principles, more so than in the Swedish text.

The PES website also includes "tips and advice" to job seekers, including how to write a successful $\mathrm{CV}$ and creating your own "personal brand". The main aspects, as stated on the webpage, are finding your "core values", answering the question "Who are you?", to choose how you want to be perceived, to stand out from the crowd, and to consider how you come across on the web as well as using social media in strengthening your personal brand. The importance of figuring out how you come across to others and building a professional work persona is explicitly stated. In this webinar and corresponding webpage, superficial attributes such as hairstyle, handshake, and tone of voice are given considerable attention. Some of these aspects may appear surprisingly shallow. However, migrants face a number of challenges related to superficial aspects such as having a foreign accent (Timming 2017) and foreign-sounding names (Agerström et al. 2012; Arai et al. 2016). To build a professional work persona and pay attention to superficial attributes is not as explicitly stated in the information regarding the introduction plan, but it would need to if it is to align with the (neoliberal) information given to a broader group of people.

Inconsistency and Excess of Information

There is ample information on the PES website directed at job seekers-including but not exclusively directed at newly arrived migrants - in the form of webpages, various questionnaires, self-assessment forms, downloadable pamphlets, and reports, as well as some webinars. A large proportion of the information is concerned with rules and procedures and comes across as based on facts. Although information undoubtedly is essential in order to increase knowledge of the Swedish labour market, the abundance of it combined with a lack of clarity can actually hamper the establishment process. It is difficult to navigate the websites, to obtain relevant and complete information, and to be referred appropriately, also for two researchers with full comprehension of English and Swedish. Links in the English version of a webpage often lead to Swedish pages, and the degree of difficulty of the Swedish language far exceeds what one could expect from a newly arrived migrant in this stage of the establishment process, although the material is directed at migrants. Advanced Swedish is also used when Swedish language comprehension is not a prerequisite for a particular education or training programme. This means that full comprehension of Swedish-or access to someone with these skills-is a necessity in order to utilize the presented information. It also appears more or less impossible to navigate through this process, and search for personally relevant 
information, without some knowledge of how Swedish society and institutions of importance function. While public officials are important as sources of information and support in the process towards gaining employment (Aslan et al. 2019; Eggenhofer-Rehart et al. 2018; Pajic et al. 2018), information should be accessible without the need for any extensive support. This is indicated by the translation of many of the webpages into the most common languages among migrants, and explicit statements that Swedish is not a prerequisite for certain training programmes.

The presented information is not always consistent. For example, the contents of the self-assessment questionnaires regarding non-academic vocations ${ }^{4}$ vary in seemingly arbitrary ways. Even though the structure of the forms follows the same format, with statements/questions and a rating scale to indicate degree of agreement, the introduction to the test differs between professions and sometimes information is omitted (e.g., tips on how to validate qualifications). Certain aspects are indeed bound to the specific profession under assessment, but it should be possible to examine generic competencies and personal characteristics in a similar way across occupations. For example, it is not obvious why a cleaner should rate their ability in meeting customers, but not a butcher, and why it is important to grade your experiences of working under stress only in some of the self-assessments ${ }^{5}$. The forms also vary in terms of how much emphasis is placed on experience compared to education/training and personal characteristics for professions with similar levels of education, as well as the amount of details in the questions examining previous experience with different parts of a profession. This lack of a systematic approach unfortunately opens up for idiosyncratic assessments of migrants' work-related skills and experiences, which in turn reduces perceptions of employability and employment opportunities.

\subsection{Social Categorizations: The Intersection of Time, Gender, Age, and Education}

A number of social categorizations emerged in the material as important for ascriptions of current as well as potential or future employability. Some of them concern classification procedures, for example, validation of prior learning (c.f. Diedrich 2017; Diedrich and Styhre 2013). There is a time aspect involved, such that a migrant can only be considered newly arrived and thus eligible for establishment measures during 3 years after residence is permitted. This time classification intersects with gender, because time on parental leave is only partly deductible from the three-year period, and the regulations concerning such deductions are complicated (e.g., Swedish Public Employment Service 2017c). Taking part in establishment measures is often not permitted when on paid parental leave, and incentives for labour market induction are thus limited. Time is also an important aspect more generally, because being unemployed for a longer period of time lowers ascriptions of employability for potential employees, since employers prefer to hire individuals with recent work experience (McQuaid and Lindsay 2002).

Gender is an all-embracing social category in the present material as well as in society in general. At times highlighted (e.g., Swedish Public Employment Service 2017b, 2017c), at other times neglected or assumed, the meaning of gender is heavily based on stereotypes, gender norms, and other preconceived ideas on how men and women could, would, and should behave. However, more often than not, norms and stereotypes are tacit and must be inferred. The context in the following quote regards the importance of parental leave in understanding problems regarding newly arrived women's establishment in the Swedish labour market:

In this context, we cannot turn a blind eye to the fact that in many other countries-including countries that are common countries of origin among those seeking asylum in Sweden-it is not evident that women should be in the labour force. It is important that the regulatory

4 Teacher was the only profession requiring an academic degree that was included in the self-assessment questionnaires, but it will not be discussed further as it differed substantially in form and content from the other questionnaires (and could be expected to differ due to the contents of the job).

5 All the self-assessment forms are currently (December 2019) available at https://arbetsformedlingen.se/other-languages/ english-engelska/sjalvskattning. 
framework they encounter in Sweden is reasonable and fair, but also clear on what is expected here.

\section{(p. 22, Swedish Public Employment Service 2017c)}

No additional explanations to what is expected in Sweden are given further on in the text, other than the general purpose that as many newly arrived migrants as possible, within the shortest time possible, should either be engaged in (permanent) employment or higher education studies with the aim of entering the labour marked when the studies are successfully concluded.

Gender persistently intersects with other categorizations to define specific and contextualised meanings. For example, sometimes the term "foreign-born women" is used (e.g., Swedish Public Employment Service 2017b), other times more specific descriptions, such as "newly arrived women migrants with uncompleted secondary school education", or "asylum seeking women from [specific country/countries/region of the world]" (e.g., Swedish Public Employment Service 2017e). Both implicitly and explicitly stated, adult migrant women are assumed to have children, with contiguous and complete responsibility for them, as well as a suspicious approach towards Swedish childcare provisions (e.g., Swedish Public Employment Service 2017b). While the accuracy of these assumptions can be and is debated, it is also important to highlight the risk of statistical discrimination of individuals when relying on group level figures and general trends (see, e.g., Arai et al. 2016). That is, even if it were true that most migrant women have child responsibilities, presuming negative ramifications due to parenthood for a particular individual is discriminatory. However, to use information and knowledge of, for example, educational attainment (lower for migrant women than men), lack of completion of the establishment plan (higher for migrant women than men), and unemployment rates (higher for migrant women and low-skilled workers than men and high-skilled workers) is a way to understand the situation and can help remedy problems. Still, there is a fine line between raising awareness of stereotypes and prejudice in order to work towards improvements, and actually reifying such preconceptions. Research on social workers in Sweden has showed the propensity to explain migrant (and not Swedish) clients' problems in terms of culture and cultural differences (Eliassi 2015). This included the reliance on stereotypes of particular social categories that were often essentialist and/or homogenized, and gendered (e.g., Muslim men vs. Muslim women). A similar propensity is found in society in general, which makes it even more important to contest such stereotypical categorizations in order to enable ascriptions of employability and facilitate labour market entrance, especially for migrant women.

Age also plays a significant, but mostly implicit, role in the ascription of employability. For example, a footnote reads: "an assessment of justification in relation to the newly arrived migrant's age should probably be made" before offering supplementary education for low-skilled women (p. 23, Swedish Public Employment Service 2017c). Otherwise the question of being too old for labour market measures is barely touched upon, but implied, for example, in the presentation of statistics and explanation of categories used in tables and figures. The ascribed meaning of a migrant's age is intertwined with other social categorizations, most prominently gender and education, and the pressing time aspect of the individual's eligibility to take part in establishment measures. Older low-skilled migrant women are placed with little potential for employability, mainly due to their lack of formal education (e.g., Swedish Public Employment Service 2017b, 2017c). The problems regarding type and length of the establishment measures to suit low-skilled women are also raised, as well as the risk of discrimination due to gender and ethnicity, both in recruitment and selection processes as well as by PES officials. Measures to counter discriminatory processes and behaviour on part of PES officials are suggested (Swedish Public Employment Service 2017b). However, many of them rely on the proposition that "Increased awareness leads to better results" (Title of main section, p. 4):

An increased awareness of how gender norms and stereotypical preconceptions about migrant women and men influence our decisions and behaviour is important for better results for foreign-born women. In order to achieve this, both education for all employees 
and further mapping and studies in the area need to be conducted and spread throughout the authority [PES] (see Section 2.2). Knowledge of everyone's equal worth, gender norms and gender equality are areas that we need to work with continuously within the authority. Additionally, more employees [at PES] need to be given the possibility to track the results within the area and at the level that each individual works.

(p. 4, Swedish Public Employment Service 2017b)

Hence, an awareness of gender norms and stereotypical thinking should be spread among the PES's managers and employees, specifically to counteract discriminatory processes regarding low-skilled migrant women. New Public Management principles of measurement and tracking of progress should also facilitate each individual official's efficiency, which links to the second types of propositions in this report that concern the development of activities for migrant women. While we do not intend to argue against any of the proposed activities, and some of these suggestions most likely can be measured (e.g., the number of migrant women in various labour market integration activities), it is problematic to equate employee participation in a course on gender norms and stereotypes or the spreading of information with individual awareness. It is even more problematic to assume behavioural and organizational changes as a consequence of this supposed awareness (for a discussion on the problems of gender equality interventions, see De Vries and van den Brink 2016; Eriksson-Zetterquist and Renemark 2016).

Low-skilled migrant men are not identified as a problematic group in terms of labour market integration. In the reports specifically concerning migrant women, framing women's lower labour market participation as highly problematic (e.g., Swedish Public Employment Service 2017b; 2017c), the relative success of low-skilled migrant men in gaining employment in Sweden is not explored further as a case of comparison or potential successful pathway towards labour market integration. While norms and stereotypes, especially concerning parenthood, are relied on to explain the situation for (low-skilled) women, such explicit and assumed preconceptions are silently lacking regarding men. The discrimination and undervaluation that high-skilled migrants face, especially men from non-Western countries (see, e.g., Edström and Pokarzhevskaya 2017; Eggenhofer-Rehart et al. 2018; Larsen et al. 2018; Mancinelli et al. 2010), is simply not addressed.

The social categorization of education is thus closely interlinked with gender and age. Migrants' levels of education vary substantially, with a large proportion lacking completed secondary school education, while a substantial amount have university degrees. Among refugees from Syria, the proportion of people who have attended university is similar to that in Sweden, but the proportion without completed secondary schooling is around 50\% (Swedish Public Employment Service 2017d). This poses substantial challenges, particularly because the time allowed in establishment measures is the same regardless of prior education. Moreover, the establishment reward system encourages unqualified work over the completion of education. Attending further education or training, even in programmes specifically targeting newly arrived migrants with prior education for professions with a shortage of employees in Sweden (so called fast tracks), was not a motive to extend a temporary residence permit for anyone over the age of 24 (SFS 2016:752 2016; Swedish Public Employment Service 2018a). The Swedish Public Employment Service (2018a) identifies potential in women such that further education within fast tracks may be pivotal to increase the proportion of migrant women in the Swedish labour force. Still, the vast majority of participants in short tracks are men, and the professions targeted are generally male dominated. Thus, there is a contradiction in both discourse and practice, such that further measures toward women's labour market integration should be beneficial, but at the same time, actual education and training programmes toward labour market integration as well as gender stereotypical discourse regarding women point towards a preference for men as participants.

To understand the process of having one's prior learning within higher education validated, we examined information from UHR (The Swedish Council for Higher Education), SACO (The Swedish Confederation of Professional Associations), and various higher education institutions. More questions than answers appear. There are different procedures depending on, for example, whether an education 
is completed or not (e.g., a complete Bachelor's degree vs. university courses within an incomplete study programme), whether the profession is regulated/requires a license to practice (e.g., clinical psychologist, teacher), and there are many local and regional variations in procedures as well as how these are explained. The central question appears to be who needs to supplement their education and why? The importance of careers and study guidance counsellors for the individual migrant in order to make sense of this process was confirmed to us by careers and study guidance counsellors and other representatives from a number of different universities in Sweden at a conference concerning labour market inclusion (e.g., Billhagen and Bäckström 2017) ${ }^{5}$.

Language skills are essential. In addition, investments in education and validation are key factors, with potential to benefit both the individual and the recipient country. Sweden has an extensive shortage of labour in certain sectors. A concurrent development is that low-skilled jobs vanish. At the same time, migrants with lower education make up a growing proportion of the newly arrived. This, in turn, stipulates that education is the most important measure in order to give newly arrived migrants the possibility to establish themselves in the labour market.

(pp. 47-48, Swedish Public Employment Service 2017e)

Education (including language acquisition and vocational training) is presented as a logical and universal solution for enabling labour market induction, and thus increasing migrants' employability. It is however proposed to function satisfactorily when tailor-made. Hence, a contradiction appears with the necessity to rely on general rules and procedures while advocating individual adaptations within a system that does not allow for these. Previous research has shown that validation of prior learning within vocations not requiring higher education is a painstaking activity that often misses its goals (see Diedrich 2017). Unfortunately, we have found similar trends regarding academic professions. Perhaps the tedious validation procedures currently in place would be redundant in a more flexible system than the present.

\section{Discussion: Towards Employability? The Neoliberal Subject in a Social Welfare System}

We have examined information directed at newly arrived migrants establishing themselves in Sweden, aiming to enter the Swedish labour market, and texts reporting on the process of labour market induction and career continuance for migrants in Sweden, most of them targeted at other government officials. The two sections of the findings (starting point vs. social categorizations) largely map onto these two perspectives, on how to make oneself employable (texts directed at job seeking migrants) versus attempting to make others employable (texts reporting on the establishment process). In itself, there is a contradiction for the PES between informing and urging migrants to attend to their own employability within a neoliberal ordering of the labour market, and to work towards making them employable by offering support and labour market measures available within the Swedish social welfare system. We have also found numerous inconsistencies in both types of texts with potential conflicts between interpretations based in neoliberal versus social welfare discourses. Other sources of confusion and obscurity relate to the sheer amount of information, detailed and difficult-to-understand regulations, and different and localised procedures relating to the validation of prior learning. When these different constructions are conveyed further, they can place various-and conflicting-implicit and explicit expectations on the individual migrant.

Previous research in Sweden (Diedrich and Styhre 2008, 2013; Vesterberg 2013, 2015, 2016a) has mainly studied constructions of migrants' employability from a policy perspective, and found similar contradictions and limitations in employability constructions (e.g., regarding categorization

5 All the self-assessment forms are currently (December 2019) available at https://arbetsformedlingen.se/other-languages/ english-engelska/sjalvskattning. 
or validation procedures). We aimed to add to the body of research by examining constructions of individual employability and labour market induction, and the role of intersecting social categorizations in these constructions. From previous research we know that the identification of employees' transferable competencies is difficult for organizations in general (Bernhard-Oettel and Näswall 2015), and the reformulation of personal assets and revaluation of previous education and work experience between contexts is problematic (e.g., Eggenhofer-Rehart et al. 2018; Larsen et al. 2018; Mancinelli et al. 2010; van Riemsdijk et al. 2016). The importance of an intersectional perspective in interpreting these processes is corroborated by research exploring employability and perceived difficulties associated with gender, actual or assumed family responsibilities, age, class, and ethnicity for individuals in or at the margins of the labour market (e.g., Allen et al. 2013; Kelan 2014; Reid and LeDrew 2013).

In the analysed texts, gender stereotypes were all pervasive but rather silent, and hardly ever explicated other than when they can be explained by statistics (e.g., proportion of parental leave among women/men). Both Kelan (2014, p. 802) and Reid and LeDrew (2013) discuss the "unspeakability of inequality", and Kelan suggests exploring its relevance in various contexts from an intersectional perspective. It would be an interesting avenue for further research to study such textual silences (see Huckin 2002; Kelan 2014) more thoroughly, as well as how gender stereotypes of migrants in Sweden differ from stereotypes of Swedish men and women, and how this in turn relates to employability constructions. Browne and Misra (2003) have argued that the stereotype of a certain ethnic group is generically male, while women are seen in line with a "universal" gender stereotype. Arai et al. (2016) interpreted their results in accordance with this proposition. In a field experiment with fictive job applicants, they found that giving Arabic women more work experience than their Swedish counterparts could compensate for the employers' preference for Swedish job applicants. However, Swedish men were still preferred over Arabic men with longer work experience. Arai et al. (2016) argued that migrant women may have a better possibility to prove their dedication to work than migrant men, because they do not fit with the stereotype in the first place, and recruiters' judgements are therefore less constrained by it. How this relates to employers' employability constructions remains to be seen. It must also be noted that work-related gender stereotypes in Sweden in part differ from more traditional, "universal" gender stereotypes (e.g., Kusterer et al. 2013).

\section{Concluding Comments}

The present study has aimed to shed light on the first part of migrants' labour market induction, by exploring how labour market induction is described, and identifying employability constructions and categorizations in the discourse used by government agencies directly involved in the labour market integration of newly arrived migrants. The construction of the employable individual in the analysed material is often based on tacit assumptions that concern the ability to bring forward required psychological and human capital in order to make oneself desirable and useful for potential employers (cf. Allen et al. 2013; Fejes 2010; Garsten and Jacobsson 2013). The terms employability or employable are not as commonly used in this type of material as one may expect, considering that it is the issue at stake. Moreover, the individual migrant is silently placed at the crossroads of two conflicting and in themselves contradictory discourses, which renders their course of action towards a secure position in the Swedish labour market challenging at best. A more serious interpretation of the effects of these contradictions would be the exclusion from more long-term appointments than temporary employment or engagement in labour market measures (c.f. Diedrich 2017), and detrimental psychological consequences as well as health repercussions (e.g., Eggenhofer-Rehart et al. 2018; Vanhercke et al. 2015).

Continued research is called for in order facilitate migrants' labour market entrance and career continuance, and to prevent any damaging psychological effects (Newman et al. 2018). A question that arises is what aspects to focus on in order to be able to reconstruct employability without damaging influence from inflexible categorizations and stereotypes. Studies among mainly Syrian refugees in Germany have raised issues such as sense of agency, resilience, vocational identity, coping, and career adaptability (Obschonka et al. 2018; Wehrle et al. 2018). These are important components related 
to employability, and should be explored further in future studies, both by looking at discursive constructions and ascriptions, migrants' own perceptions, as well as the link between ascriptions and individual perceptions. The process of giving voice to marginalised groups in order to enhance a sense of agency that would facilitate career development and re-contextualisation of job skills should not be neglected (Abkhezr et al. 2018). Along these lines, it will be important for future research to investigate different perspectives on migrants' employability constructions and measures to facilitate labour market entrance, through examining the views of migrants, facilitators such as organizers of vocational training and language programmes, employers, and government officials.

Author Contributions: Conceptualization, H.L.K. and C.B.-O.; methodology, H.L.K.; formal analysis, H.L.K.; writing-original draft preparation, H.L.K.; writing-review and editing, H.L.K. and C.B.-O.; funding acquisition, H.K. All authors have read and agreed to the published version of the manuscript.

Funding: This research was supported by a seed grant from the Centre for Global Human Resource Management, Gothenburg University, and additional funds from the Faculty of Health and Occupational Studies, University of Gävle, granted to the first author.

Conflicts of Interest: The authors declare no conflict of interest.

\section{References}

Abkhezr, Peyman, Mary McMahon, Kevin Glasheen, and Marilyn Campbell. 2018. Finding voice through narrative storytelling: An exploration of the career development of young African females with refugee backgrounds. Journal of Vocational Behavior 105: 17-30. [CrossRef]

Acker, Joan. 1990. Hierarchies, jobs, bodies: A theory of gendered organizations. Gender and Society 4: 139-58. [CrossRef]

Acker, Joan. 2006. Inequality regimes: Gender, class, and race in organizations. Gender and Society 20: 441-64. [CrossRef]

Agerström, Jens, Fredrik Björklund, Rickard Carlsson, and Dan-Olof Rooth. 2012. Warm and competent Hassan $=$ Cold and incompetent Eric: A harsh equation of real-life hiring discrimination. Basic and Applied Social Psychology 34: 359-66. [CrossRef]

Allen, Kim, Jocey Quinn, Sumi Hollingworth, and Anthea Rose. 2013. Becoming employable students and "ideal" creative workers: exclusion and inequality in higher education work placements. British Journal of Sociology of Education 34: 431-52. [CrossRef]

Arai, Mahmood, Moa Bursell, and Lena Nekby. 2016. The reverse gender gap in ethnic discrimination: Employer stereotypes of men and women with Arabic names. International Migration Review 50: 385-412. [CrossRef]

Aslan, Pinar, Nader Ahmadi, Stefan Sjöberg, and Eva Wikström. 2018. What works? Family influences on occupational aspirations among descendants of Middle Eastern immigrants on the Swedish labour market. Nordic Journal of Social Research 9: 134-60. [CrossRef]

Aslan, Pinar, Stefan Sjöberg, Eva Wikström, and Nader Ahmadi. 2019. Door openers? Public officials as supportive actors in the labour market participation of descendants of immigrants in Sweden. Nordic Social Work Research. [CrossRef]

Berglund, Tomas, Kristina Håkansson, Tommy Isodorsson, and Johan Alfonsson. 2017. Temporary employment and the future labor market status. Nordic Journal of Working Life Studies 7: 27-48. [CrossRef]

Bergström, Göran, and Kristina Boréus. 2005. Textens Mening och Makt. Metodbok i Samhällsvetenskaplig Textanalys. Lund: Studentlitteratur.

Bernhard-Oettel, Claudia, and Katharina Näswall. 2015. Career continuance and transfer of competencies after job transitions: Insights from a Swedish study. In Handbook of Research on Sustainable Careers. Edited by Beatrice van der Heijden and Ans De Vos. Cheltenham: Edward Elgar, pp. 381-97.

Berntson, Erik. 2008. Employability Perceptions-Nature, Determinants, and Implications for Health and Well-Being. Ph.D. dissertation, Stockholm University, Stockholm, Sweden.

Berntson, Erik, Magnus Sverke, and Staffan Marklund. 2006. Predicting perceived employability: Human capital or labour market opportunities? Economic and Industrial Democracy 27: 223-44. [CrossRef] 
Berntson, Erik, Katharina Näswall, and Magnus Sverke. 2008. Investigating the relationship between employability and self-efficacy: A cross-lagged analysis. European Journal of Work and Organizational Psychology 17: 413-25. [CrossRef]

Billhagen, Mia, and Carina Bäckström. 2017. NYAK ett samverkansprojekt mellan lärosätena i Skåne och Arbetsförmedlingens etableringskontor [NYAK a co-operation project between higher education institutions and the Public Employment Service's establishment offices]. Paper presentation at Include Conference 2017: Entry, Supply, and Access to Higher Education, Gävle, Sweden, October 17-19.

Bowen, Glenn A. 2009. Document analysis as a qualitative research method. Qualitative Research Journal 9: 27-40. [CrossRef]

Braun, Virginia, and Victoria Clarke. 2013. Successful Qualitative Research: A Practical Guide for Beginners. London: Sage.

Browne, Irene, and Joya Misra. 2003. The intersection of gender and race in the labour market. Annual Review of Sociology 29: 487-513. [CrossRef]

Calas, Marta B., and Linda Smircich. 2006. From the 'woman's point of view' ten years later: Towards a feminist organization studies. In The SAGE Handbook of Organization Studies. Edited by Stewart R. Clegg, Cynthia Hardy, Thomas B. Lawrence and Walter R. Nord. Thousand Oaks: Sage, pp. 284-347.

Crawley, Heaven, and Dimitris Skleparis. 2018. Refugees, migrants, neither, both: categorical fetishism and the politics of bounding in Europe's 'migration crisis'. Journal of Ethnic and Migration Studies 44: 48-64. [CrossRef]

Croucher, Richard, Sumeetra Ramakrishnan, Marian Rizov, and Diana Benzinger. 2018. Perceptions of employability among London's low-paid: 'Self-determination' of ethnicity? Economic and Industrial Democracy 39: 109-30. [CrossRef]

Davies, Bronwyn, Jenny Browne, Susanne Gannon, Eileen Honan, and Margaret Somerville. 2005. Embodied women at work in neoliberal times and places. Gender, Work and Organization 12: 343-62. [CrossRef]

De los Reyes, Paulina. 2014. Introduktion-Inte bara jämställdhet [Introduction-Not just gender equality]. In SOU 2014:34 Inte Bara Jämställdhet. Intersektionella Perspektiv på Hinder och Möjligheter i Arbetslivet [Not Just Gender Equality. Intersectional Perspectives on Obstacles and Possibilities in Working Life]. Stockholm: Fritzes, pp. 9-33.

De Vries, Jennifer Anne, and Marieke van den Brink. 2016. Transformative gender interventions. Linking theory and practice using the "bifocal approach". Equality, Diversity and Inclusion: An International Journal 35: 429-48. [CrossRef]

Diedrich, Andreas. 2017. Validation of immigrants' prior foreign learning as a framing practice. European Management Journal 35: 729-36. [CrossRef]

Diedrich, Andreas, and Alexander Styhre. 2008. Making the refugee multiple: The effects of classification work. Scandinavian Journal of Management 24: 330-42. [CrossRef]

Diedrich, Andreas, and Alexander Styhre. 2013. Constructing the employable immigrant: The uses of validation practices in Sweden. Ephemera: Theory and Politics in Organizations 13: 759-83.

Edström, Josefin, and Galina Pokarzhevskaya. 2017. Lönegap mellan akademiker med svensk och utländsk bakgrund. En analys av Sacoförbundens medlemmar [Salary Gap between Academics with Swedish and Foreign Background. An Analysis of the SACO-Union Members]. Report. SACO. Available online: http://www.saco.se/ (accessed on 7 July 2018).

Eggenhofer-Rehart, Petra M., Markus Latzke, Katharina Pernkopf, Dominik Zellhofer, Wolfgang Mayrhofer, and Johannes Steyrer. 2018. Refugees' career capital welcome? Afghan and Syrian refugee job seekers in Austria. Journal of Vocational Behavior 105: 31-45. [CrossRef]

Eliassi, Barzoo. 2015. Constructing cultural Otherness within the Swedish welfare state: The cases of social workers in Sweden. Qualitative Social Work 14: 554-71. [CrossRef]

Eriksson-Zetterquist, Ulla, and David Renemark. 2016. Can changes to gender equality be sustained? Gender, Work and Organization 23: 363-78. [CrossRef]

Fairclough, Norman. 2003. Analysing Discourse. Textual Analysis for Social Research. London: Routledge.

Fejes, Andreas. 2010. Discourses on employability: constituting the responsible citizen. Studies in Continuing Education 32: 89-102. [CrossRef]

Fugate, Mel, Angelo J. Kinicki, and Blake E. Ashforth. 2004. Employability: A psycho-social construct, its dimensions, and applications. Journal of Vocational Behavior 65: 14-38. [CrossRef] 
Garsten, Christina, and Kerstin Jacobsson. 2013. Sorting people in and out: The plasticity of the categories of employability, work capacity and disability as technologies of government. Ephemera: Theory and Politics in Organizations 13: 825-50.

Gazso, Amber. 2007. Balancing expectations for employability and family responsibilities while on social assistance: Low-income mothers' experiences in three Canadian provinces. Family Relations 56: 454-66. [CrossRef]

Huckin, Thomas. 2002. Textual silences and the discourse of homelessness. Discourse and Society 13: $347-72$. [CrossRef]

Irastorza, Nahikari, and Pieter Bevelander. 2017. The labour market participation of humanitarian migrants in Sweden: An overview. Intereconomics 2017: 270-77. [CrossRef]

Kelan, Elisabeth K. 2014. From biological clocks to unspeakable inequalities: The intersectional positioning of young professionals. British Journal of Management 25: 790-804. [CrossRef]

Kusterer, Hanna Li. 2014. Gender equality and liberal individualism: A critical reading of economist discourse in Sweden. Scandinavian Journal of Management 30: 306-16. [CrossRef]

Kusterer, Hanna Li, Torun Lindholm, and Henry Montgomery. 2013. Gender typing in stereotypes and evaluations of actual managers. Journal of Managerial Psychology 28: 561-79. [CrossRef]

Larsen, Edvard N., Adrian F. Rogne, and Gunn E. Birkelund. 2018. Perfect for the job? Overqualification of immigrants and their descendants in the Norwegian labor market. Social Inclusion 6: 78-103. [CrossRef]

Mäkikangas, Anne, Nele De Cuyper, Saija Mauno, and Ulla Kinnunen. 2013. A longitudinal person-centred view on perceived employability: The role of job insecurity. European Journal of Work and Organizational Psychology 22: 490-503. [CrossRef]

Mancinelli, Susanna, Massimiliano Mazzanti, Nora Piva, and Giovanni Ponti. 2010. Education, reputation or network? Evidence on migrant workers employability. The Journal of Socio-Economics 39: 64-71. [CrossRef]

Martin, Patricia Yancey. 2003. "Said and done" versus "saying and doing". Gendering practices, practicing gender at work. Gender and Society 17: 342-66. [CrossRef]

Martin, Patricia Yancey. 2006. Practising gender at work: Further thoughts on reflexivity. Gender, Work and Organization 13: 254-76. [CrossRef]

McQuaid, Ronald W., and Colin Lindsay. 2002. The 'employability gap': long-term unemployment and barriers to work in buoyant labour markets. Environment and Planning C: Government and Policy 20: 613-28. [CrossRef]

Miller, Linda, Andy Biggart, and Becci Newton. 2013. Basic and employability skills. International Journal of Training and Development 17: 173-75. [CrossRef]

Newman, Alexander, Jenny Bimrose, Ingrid Nielsen, and Hannes Zacher. 2018. Vocational behavior of refugees: How do refugees seek employment, overcome work-related challenges, and navigate their careers? Journal of Vocational Behaviour 105: 1-5. [CrossRef]

Obschonka, Martin, Elisabeth Hahn, and Nida ul Habib Bajwa. 2018. Personal agency in newly arrived refugees: The role of personality, entrepreneurial cognitions and intentions, and career adaptability. Journal of Vocational Behavior 105: 173-84. [CrossRef]

Pajic, Sofija, Magdalena Ulceluse, Gábor Kismihók, Stefan T. Mol, and Deanne N. den Hartog. 2018. Antecedents of job search self-efficacy of Syrian refugees in Greece and the Netherlands. Journal of Vocational Behaviour 105: 159-72. [CrossRef] [PubMed]

Reid, Colleen, and Robin A. LeDrew. 2013. The burden of being "employable": Underpaid and unpaid work and women's health. Affilia: Journal of Women and Social Work 28: 79-93. [CrossRef]

Saxonberg, Steven, and Lena Sawyer. 2006. Uteslutningsmekanismer och etnisk reproduktion inom Akademin [Exclusion mechanisms and ethnic reproduction within Academia]. In SOU 2006:40 Utbildningens Dilemma. Demokratiska Ideal och Andrafierande Praxis [The Dilemma of Education. Democratic Ideals and Othering Practices]. Stockholm: Fritzes, pp. 405-63.

SFS 2016:752. 2016. Lag (2016:752) om Tillfälliga Begränsningar av Möjligheten att få Uppehållstillstånd i Sverige; Stockholm: Sveriges Riksdag.

Statistics Sweden. 2014. Arbetskraftsundersökningarna (AKU) 1:a kvartalet 2014-Tema utrikes föddas arbetsmarknadssituation 2005-13. Available online: http://www.scb.se/ (accessed on 29 November 2016).

Statistics Sweden. 2018. På tal om Kvinnor och Män, Lathund om Jämställdhet 2018 [Women and Men in Sweden, Facts and Figures 2018]; Örebro: SCB. Available online: http://www.scb.se/ (accessed on 3 July 2018). 
Swedish Migration Agency. 2018a. Asylsökande till Sverige under 2000-17. Available online: http://www. migrationsverket.se/ (accessed on 3 July 2018).

Swedish Migration Agency. 2018b. Beviljade uppehållstillstånd 2009-17. Available online: http://www. migrationsverket.se/ (accessed on 3 July 2018).

Swedish Public Employment Service. 2016a. Arbetsförmedlingens lägesbedömning av arbetet med snabbspåren. Available online: https://www.arbetsformedlingen.se/ (accessed on 21 January 2017).

Swedish Public Employment Service. 2016b. Welcome to Arbetsförmedlingen. Available online: https: //www.arbetsformedlingen.se/ (accessed on 28 February 2017).

Swedish Public Employment Service. 2017a. Arbetsförmedlingens verksamhetsstatistik december 2016. Färre arbetslösa 2016. Available online: https://www.arbetsformedlingen.se/ (accessed on 12 January 2017).

Swedish Public Employment Service. 2017b. Arbetsförmedlingens Återrapportering 2017. Handlingsplan för att fler utrikes födda kvinnor ska vara sysselsatta i arbete eller studier, 2017-18. Available online: https://www.arbetsformedlingen.se/ (accessed on 10 October 2017).

Swedish Public Employment Service. 2017c. Har vi större problem med nyanlända kvinnors etablering och beror det i så fall på ett systemfel? Working paper 2017:6. Available online: https://www.arbetsformedlingen.se/ (accessed on 10 October 2017).

Swedish Public Employment Service. 2017d. Perspektiv på etableringsuppdraget. Available online: https: //www.arbetsformedlingen.se/ (accessed on 10 October 2017).

Swedish Public Employment Service. 2017e. Kunskapsöversikt: Nyanländas etablering på den svenska arbetsmarknaden. Working paper 2017:5. Available online: https://www.arbetsformedlingen.se/ (accessed on 10 October 2017).

Swedish Public Employment Service. 2018a. Arbetsförmedlingens nulägesbedömning av arbetet med snabbspår. Juni 2018. Available online: https://www.arbetsformedlingen.se/ (accessed on 4 July 2018).

Swedish Public Employment Service. 2018b. Arbetsförmedlingen. Månadsstatistik 2018-05. Available online: https://www.arbetsformedlingen.se/Om-oss/Statistik-och-publikationer/Statistik/Manadsstatistik. html (accessed on 4 July 2018).

Swedish Public Employment Service. 2019. Lägre andel nyanlända kommer till etableringen. Konsekvenser av tillfälliga uppehållstillstånd. Arbetsförmedlingen analys 2019:9. Available online: https://www. arbetsformedlingen.se/ (accessed on 22 January 2020).

Timming, Andrew R. 2017. The effect of foreign accent on employability: A study of the aural dimensions of aesthetic labour in customer-facing and non-customer-facing jobs. Work, Employment and Society 31: 409-28. [CrossRef]

van Riemsdijk, Micheline, Scott Basford, and Alana Burnham. 2016. Socio-cultural incorporation of skilled migrants at work: Employer and migrant perspectives. International Migration 54: 20-34. [CrossRef]

Vanhercke, Dorien, Nele De Cuyper, Ellen Peeters, and Hans De Witte. 2014. Defining perceived employability: a psychological approach. Personnel Review 43: 592-605. [CrossRef]

Vanhercke, Dorien, Kaisa Kirves, Nele De Cuyper, Marijke Verbruggen, Anneleen Forrier, and Hans De Witte. 2015. Perceived employability and psychological functioning framed by gain and loss cycles. Career Development International 20: 179-98. [CrossRef]

Vertovec, Steven. 2007. Super-diversity and its implications. Ethnic and Racial Studies 30: 1024-54. [CrossRef]

Vesterberg, Viktor. 2013. Ethnicized un/employability: Problematized others and the shaping of advanced liberal subjects. Ephemera: Theory and Politics in Organization 13: 737-57.

Vesterberg, Viktor. 2015. Learning to be Swedish: Governing migrants in labour market projects. Studies in Continuing Education 37: 302-16. [CrossRef]

Vesterberg, Viktor. 2016a. Exploring misery discourses: Problematized Roma in labour market projects. European Journal for Research on Education and Learning for Adults 7: 25-40. [CrossRef]

Vesterberg, Viktor. 2016b. Ethnicizing Employability. Governing the Unemployed in Labour Market Projects in Sweden. Ph.D. dissertation, Linköping University, Linköping, Sweden.

Wehrle, Katja, Ute-Christine Klehe, Mari Kira, and Jelena Zikic. 2018. Can I come as I am? Refugees' vocational identity threats, coping and growth. Journal of Vocational Behavior 105: 83-101. [CrossRef] 
West, Candace, and Don H. Zimmerman. 1987. Doing gender. Gender and Society 1: 125-51. [CrossRef] World Economic Forum. 2020. The Global Gender Gap Report 2020. Cologny and Geneva: World Economic Forum.

(C) 2020 by the authors. Licensee MDPI, Basel, Switzerland. This article is an open access article distributed under the terms and conditions of the Creative Commons Attribution (CC BY) license (http://creativecommons.org/licenses/by/4.0/). 